\title{
Parents Involvement in Implementation of Career Transition for Students with Learning Disabilities from a Teacher's Perspective in Malaysia
}

Noraini Abdullah, Rohaizat Ibrahim

To Link this Article: http://dx.doi.org/10.6007/IJARBSS/v11-i8/10418

DOI:10.6007/IJARBSS/v11-i8/10418

Received: 06 June 2021, Revised: 11 July 2021, Accepted: 30 July 2021

Published Online: 18 August 2021

In-Text Citation: (Abdullah \& Ibrahim, 2021)

To Cite this Article: Abdullah, N., \& Ibrahim, R. (2021). Parents Involvement in Implementation of Career Transition for Students with Learning Disabilities from a Teacher's Perspective in Malaysia. International Journal of Academic Research in Business and Social Sciences, 11(8), 1047-1059.

\section{Copyright: @ 2021 The Author(s)}

Published by Human Resource Management Academic Research Society (www.hrmars.com)

This article is published under the Creative Commons Attribution (CC BY 4.0) license. Anyone may reproduce, distribute, translate and create derivative works of this article (for both commercial and non-commercial purposes), subject to full attribution to the original publication and authors. The full terms of this license may be seen at: http://creativecommons.org/licences/by/4.0/legalcode

Vol. 11, No. 8, 2021, Pg. 1047 - 1059

Full Terms \& Conditions of access and use can be found at http://hrmars.com/index.php/pages/detail/publication-ethics 


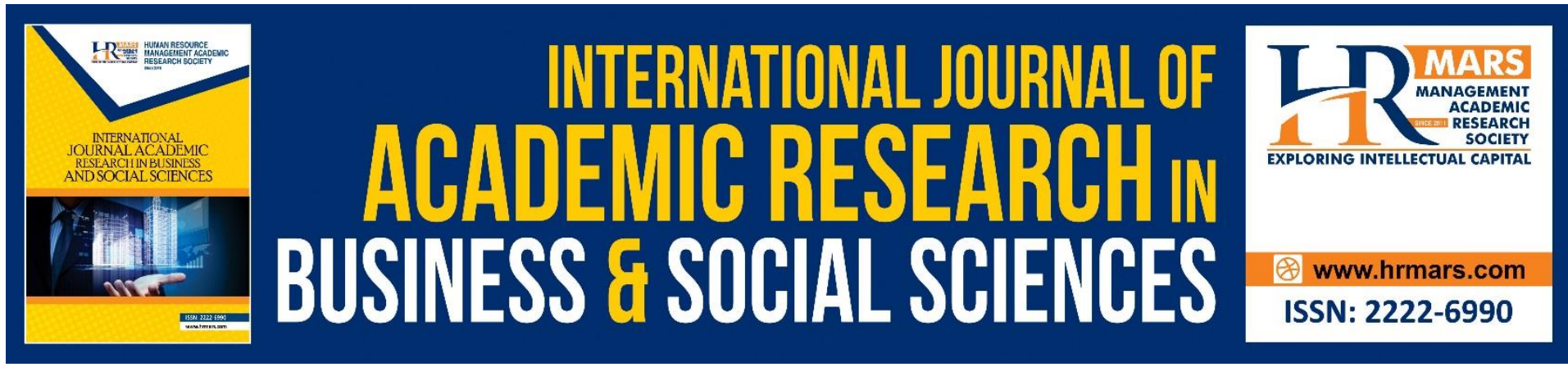

\title{
Parents Involvement in Implementation of Career Transition for Students with Learning Disabilities from a Teacher's Perspective in Malaysia
}

\author{
Noraini Abdullah, Rohaizat Ibrahim \\ Special Education Department, Faculty of Human Development, Sultan Idris Education \\ University, 35900 Tanjong Malim, Perak, Malaysia \\ Email: noraini.abdullah@fpm.upsi.edu.my
}

\begin{abstract}
Parents' involvement is one factor that contributes to implementing career transition for students with learning disabilities (SLD) in the Special Education Integration Program (SEIP). The involvement in educating children at school could also nurture their psychological growth, sharing learning experiences, supporting and respecting the teachers' effort. This research explored parents' involvement and the obstacles they face in implementing career transition for students with learning disabilities (SLD) in Special Education Integration Program (SEIP) from a teacher's perspective in Malaysia. This research uses a qualitative and case study design. Data collection is through interviews with vocational subject teachers at SEIP. Four teachers at three secondary schools in Johore and Malacca were chosen based on a purposeful sampling technique. The data were analyzed using the ATLAS.ti 8 software. Findings show that parents' involvement at suburban schools is better than in urban schools. Parent's involvement in career transition for SLD in SEIP is from the execution of the Individual Education Program (IEP), supports and encouragement, the contribution of ideas and needs, commercializing works from SLD, and seeking job opportunities after finishing their work school. Besides that, the parents face a few obstacles in implementing career transition for SLD, such as not being interested in the activities held by the school, being busy with work and transferring all the responsibilities of educating SLD to the teachers at SEIP. Hopefully, this research could open up our minds to the importance of parents' involvement in accomplishing the career transition for SLD at SEIP. Parents' involvement in the career transition is vital to prepare the SLD with various skills before entering the workplace.
\end{abstract}

Keywords: Career Transition, Involvement, Parents, Students with Learning Disabilities, Special Education Integration Program.

\section{Introduction}

A career transition is a comprehensive program that contains lessons and components of the services needed by a student with special needs to help them achieve their education, career and life goals independently (Mazzotti et al., 2014). Based on research by Alias (2014), 
students with special needs will benefit from the transition program. They were acquiring experience in specific fields of work, obtaining educational opportunities that suit their ability and potential and getting trained in a skill-focused education program using technical and vocational curricula instead of following the existing academic curriculum. According to Landmark et al (2010), one of the aspects in the best practice of career transition implementation is through the vocational education-based curriculum. A study by Mustapha (2004) showed that vocational education is necessary for preparing students with special needs to compete in the job market. Vocational education and training are efforts to develop the ability of students with special needs in preparation for employment and acquire skills that enable them to get a job (Yusof et al., 2014).

The Persons with Disabilities ACT (2008) states that persons with disabilities should include the general education system, including preschool, primary, secondary and tertiary education, vocational training, and lifelong learning due to their disabilities experience. A career transition program was essential to students with learning disabilities (SLD) because these groups cannot master the academic field. However, they can work (Maslinda et al., 2012). SLD are students whom clinical professionals confirm as having a disability that interferes with the learning process. However, they can attend schooling through inclusive programs or Special Education Integration Program (SEIP) either in primary and regular day secondary schools or attend schooling in special education primary school (Zalizan, 2009). Learning disabilities refer to a group of heterogeneous disorders which may affect the acquisition, organization, retention, understanding or use of verbal or nonverbal information (Al-Mahrezi et al., 2016). According to Social Welfare Department (2019), SLD can categorize according to the level of functionality of students in the following abilities such as Global Development Delay (GDD), Down Syndrome, Attention Deficit Hyperactivity Disorder (ADHD), Autism, Intellectual, Specific Learning Disability.

To comply with the integrated support system for the students, schools need to build a partnership with parents and develop mutual responsibility for children's success in the educational system. Ibrahim et al. (2021) study show that SLD has to learn some skills to improve its quality of life. In this way, parental involvement increases, parents' effort to support schools is encouraged, and directly impacting a successful educational system (Durisic \& Bunijevac, 2017). To ensure the successful implementation of the transition program, SLD needs to be guided and assisted in increasing their potential and unearthing the hidden talents within each other. The role of the family has a significant impact on success in the transition program for SLD from school to the work realm (Reichman \& Jacoby, 2010). Parental involvement is an effective way to design educational programs to meet students' disabilities based on differences in disabilities, degrees, and types of problems or disabilities impacting their learning (Al-Shammari \& Yawkey, 2008). Through parental involvement in the child, education can enhance the interaction between parents and their child. For Tozer et al. (2006), parental involvement in children's education at school can help parents in psychological growth, share learning experiences, and support and respect teachers' efforts.

Based on the Taxonomic Model by Kohler (2003), parental involvement contains three components that help increase the value of parental commitment in the transition planning process. The first component is parental involvement, including participation in the policymaking, delivery of service, evaluation and decision-making stages, and the inclusion of 
parents as coaches, mentors, and support networks in the transition planning process. The second component of family involvement is parental jurisdiction, including Individualized Education Program (IEP) pre-planning, child care for families, and structured methods for identifying family needs. Parents express better participation when schools strive to share information and work together to foster partnerships (Defur et., 2001). The third component is parents' training, which includes the practices required by parents such as selfdetermination, advocation, support, IEP procedures, and knowledge of relevant agencies.

However, past studies have found barriers towards parental involvement in the implementation of career transition. Samian and Buntat (2012) found that the lack of parental involvement is a massive obstacle in implementing transition programs. Grigal and Neubert (2004) show that parents and professionals, including teachers, have difficult experiences collaborating effectively. In addition, parents involved in special education programs played a passive role in programs outside the classroom and no collaboration was reported in teaching and learning in the classroom. The presence of parents at school is only to fulfil the conditions or invitation of teachers. Parents listen and accept the teacher's suggestions without much question (Mashitah, 2009). A study by Norshidah et al (2003) stated that one of the main reasons for the lack of parental involvement in school is communication problems between teachers and parents. The findings of this study are the same as Martin et al. (2006), who found that schools' failure towards parental involvement was because most schools practiced one-way communication and teachers provide fewer opportunities for parents to talk or give ideas. Based on the constraints faced by parents in previous studies, the researcher conducted this study to explore parental involvement and identify the constraints parents face in the implementation of SLD career transition in SEIP.

\section{Methodology}

This study used a qualitative approach and case study design. Three schools in the Special Education Integration Program (SEIP) in Johore and Malacca are involved in this research. SEIP was selected because it was the first school to begin implementing vocational education for students with learning disabilities in Malaysia. This study used the purposive sampling method. Through purposive sampling, it will assist in accessing research sites more efficiently, get more detailed information, and answer the research questions. The participants in this study were between 25 to 45 years and have experience teaching between 5 to 20 years. An interview protocol was developed based on previous studies and adapted from Taxonomy for Transition Programming. Interviews in this study used checklists and questions in the form of semi-structured interview protocol to build the researcher's confidence. The interviews were done twice. A total of four teachers in SEIP were involved in this interview. The interview was around 45 minutes individually. In addition, all critical information is a record in MP3 and notebook. All interviews were audio-recorded and transcribed. All data were processed, analyzed and managed using a computer program from ATLAS.ti 8 to get the themes and answer the research questions.

\section{Findings}

The findings of the study are to answer two research questions, (i) to explore the involvement of parents in the career transition of SLD in SEIP and (ii) identify the constraints faced by parents in the implementation of career transition of SLD in SEIP. 
Exploring Parental Involvement in SLD Career Transition at SEIP

The results of the study found that parents in rural schools were more involved in the career transition of SLD in SEIP compared to parents in urban areas. The results showed that there were five themes related to parental involvement, namely the implementation of IEP, providing support and encouragement, contributing ideas and necessities, helping to market work, and finding employment opportunities for SLD after they finish school.

a. Implementation of Individualized Education Program (IEP)

Parental involvement in the implementation of the IEP is a very important element so that all decisions are made together to determine what the SLD needs and how the IEP can be implemented more effectively. The findings of the study showed that parents in S1, S2, S3, were actively involved in IEP meetings in their children's schools. The involvement of parents in IEP meetings is to obtain information and hold discussions related to the programs conducted in the school.

"I am thankful for the parents' involvement because I did so myself on the first day of school, I explained to all the caretakers of the programs that will take place throughout the year, bits by bits on all our modules and what will their children be learning during students' registration." (G1S1)

“... parents' involvement was okay, even though not all parents would actually come when we invite them for any meetings... they chose to be presence mostly during meetings, such as parent and teacher association meetings or IEP meetings" (G3S2)

Add G1 again, once all students are divided according to their respective classes, parents can come to the school to see for themselves what programs are taught for their children and then sign the IEP form that has been prepared by the school. If parents do not agree with a program taught in the school, they have the right to make recommendations to the teacher to make amendments to the program.

"... the parents could come and listen to all the specified programs for their child, and here is when they will leave a signature on the consent form.. if there is any amendment, we would adjust accordingly to meet their agreement before they could leave a signature on the form itself ..." (G1S1)

Consent from parents is very important to make sure they know what their child is learning in school. Through the meetings attended, parents will find out about their children's development as well as what their children are learning in school. In addition, teachers can also find out what parents want on the skills that need to be taught to their children.

"... whenever we called the parents for IEP meetings, we would tell them on what their children has learnt, what have they been involved with and which skills or subjects that the children had more or less progress and development. We really ensure all the parents knew what activities were being held by our teachers at school" (G4S3) 
"... discussion was done first with the parents, whereby they would come and tell us.. teacher, I'm opening a store and wished to have my child working with me at the store, to help me with these and that.. so we would teach and educate the child as to what the discussion with the parents wish to produce ..." (G3S2)

b. Provide Support and Encouragement

The findings of the study showed that parents in S1-S3 have given support in the form of encouragement to SLD in IEP by asking their children to practice what they have learned at home. This can indirectly realize the continuity of what has been learned in school with what is practiced by SLD at home.

"Some of the parents are to be idolized, they encourage their children to practice what they have learnt at school .. like this one parents .. they always brings their child to the farm .. it shows that the parents knew their responsibilities at home to educate their children..." (G1S1)

“... the parents' support are very good .. they would say .. teacher, if my child is less brilliant, please educate them, I don't know how to educate, but I would truly support

.. after this my child could cook at home and plus I also has a restaurant ..." (G3S2)

According to G5, for their children who are already good at sewing, parents will buy a sewing machine as an incentive for them to work as seamstresses.

"Their child may not be brilliant in academic, so I focused on sewing, now the child could sew, their parents bought them a sewing machine, so that the child could practice sewing at home, this makes the parents happy to see their child is mastering a new skill..." (G4S3)

c. Contribution of Ideas and Necessities

Parental involvement with the school is also through contributions in the form of ideas and necessities. For S1 who implement agricultural vocational skills, the support given is more to support ideas such as how to produce good seeds, provide seeds to the school and provide necessary materials for the use of SLD in IEP.

"...they are less fortunate, in terms of contributions of ideas, is how to produce a good seed. Some parents even willing to come to school to teach us on how to plant and take care of the plant, so we teachers also get some new knowledge.."(G2S1)

"Sometimes I would ask for some of the seeds that is not available at the schools, the parents would respond immediately, suddenly one of my student would say .. my mom had prepared the rossele seeds teacher, and this is one of the ways how the parents would help us ..." (G1S1) 
There are also parents who are willing to help teachers in learning activities at school. There is a mother of a student in our school who works as a seamstress, and she is willing to teach SLD and also the teachers at SEIP to sew beads.

"There are a number of very committed parents, that wills to sit down together with the teachers. Once, there was a parent who teaches on beads, they bought the beads, and teaches the teachers on how to make the beads art, we teachers learn a lot from the parents" (G5S3)

d. Tours and Exhibitions

Parents are also involved in visiting activities organized by the school. In addition to strengthening the relationship between parents and the school, the involvement of parents can also help teachers in maintaining the safety of students. In addition, parents who follow the group with their children are able to find out the job opportunities that are right for their children.

\begin{abstract}
"Most trips that we do are to vegetables farms, orchards like guava, papaya, starfruit, sapodilla and many more .. some of the parents even join us for the trips so that they know what their child are capable of after graduating from SEIP later on.." (G1S1)

"We bring both parents and students to relate anything that have a career potential... we said to the students, look at what they are ding, later on you can do it too by yourself, that's how we relate the career trip with the students .." (G3S2)
\end{abstract}

The same goes for the involvement of parents when the school holds exhibitions outside the school. There are parents who help find financial resources to help the school during the exhibition activities. Support is also given to help the school sell SLD's work.

"... if there is any exhibitions held, we would inform the parents to find external contributions.. some of the parents are willing to find sponsorships and ring the goods themselves to the exhibitions..." (G4S3)

"... some of the parents involve with business.. there are some parents who would like to order bedsheets, they asked us to sew for them and later the parents will help to sell it out, like right now.. we make covers for dustbin, skirts and also curtains..." (G4S3)

e. Job Opportunities

There are parents in S2 who invite SLD to work if there are job opportunities for SLD such as working in a factory and trading burgers. Such parental involvement can indirectly provide information to the SLD on employment opportunities according to their abilities.

"... sometimes the parents remind the teachers on job vacancies that the students can apply. That's the beauty of parent-teacher interactions, some 
of the parents worked at a factory and when there is a vacancy they would offer to the children" (G3S2)

"... for examples some of the villagers knew that the students can cook, they would inform the teacher, there is an empty stall, why don't you ask the students to start selling burger or something.." (G3S2)

\subsection{Constraints on parental involvement in the SLD career transition program at SEIP}

The results of the study found that the attitude of parents is a major constraint in implementing the career transition of SLD in SEIP. The findings of the study showed that parents from rural schools were more actively involved in activities organized by the school compared to parents in urban schools. The results of the study found that the attitude of parents such as not interested in activities implemented in school, busy with work and put full responsibility on teachers at SEIP to educate their children.

a. Not Interested in Activities Implemented in School.

The findings of the study show that there are parents, especially in urban schools, are not interested in participating in activities carried out by the school. This is because they do not have time and are always busy with their work.

"..we do call the parents to school .. asking them to observe our method .. like at this school, we get orders for bedsheets, pillow cases, dustbin covers .. but the parents didn't come, maybe they're not interested.." (G4S3)

".. whenever we held a cooking competition, we invite the parents to school.. witnessing their child's talent in cooking, however, not many actually came..." (G3S2)

b. Busy with Work

Most parents stated that they could not get involved in the activities carried out in school because they were busy with work, especially parents in urban schools. Usually, parents will ask teachers to talk about their children's progress over the phone only.

"... if there are any activities being held, there are parents that came.. but not all as there are quite a challenge for working parents to come to the school..." (G2S1) "... certain parents are uncooperative.. but they have their reasons, they are busy and time constraint.. they hope the teachers could educate their children.." (G3S2) "I must say, the number of parents' involvement here is quite low.. we did call but.. they are all busy, that's it.. they even requested for us to update them by the phone on their child's development.." (G4S3)

c. Delegate Responsibilities to Teachers

Due to the busyness of the parents, they completely hand over the responsibility of educating their children to the school. They fully support what teachers are teaching their children. 
"... parents do support us on our teaching methods and materials for their children, they give a $100 \%$ responsibilities to the teachers to build up any skills for their children.." (G1S1) .

In terms of decision makers, the results of the study show that the majority of parents only follow whatever decisions are made by the school on the implementation of vocational subjects for SLD in SEIP. The results of the interviews also found that there are still many parents who do not know about the implementation of career transition carried out in schools.

"... in decision making.. usually the parents would just follow the schools" decision

(G4S3)

"... there are even parents who don't know what activities that we do with their children unless we update and explain to them, then only will they understand.." (G3S2)

\section{Discussion and Implication}

Parental involvement is one factor that contributes to the successful implementation of career transition through vocational subjects for SLD in SEIP. The results showed that parental involvement in the SLD career transition was not comprehensive. Parents in rural schools were more involved in career transition than parents in urban schools. The results showed that parents were involved in implementing EIP, providing support and encouragement, contributing ideas and necessities, marketing SLD work and looking for employment opportunities for SLD after they finish school. Various support parents give to the school can help the successful implementation of the SLD career transition in SEIP. Lubbers et al. (2008) found that parents are the primary support to special education teachers, and if parents are involved in the transition process, then student involvement will also improve. Kochhar-Bryant and Green (2009) also stated that special needs families need to be fully involved in the transition planning process.

The results show that the most parental involvement is through the implementation of IEP. Through the IEP meetings held, parents can find out their children's development, such as what is learned in school, their children's needs, and how their children are achieving in school. Through the involvement of parents in the implementation of the IEP will provide an opportunity for them to voice their views and share ideas in planning MMP interventions. These findings are supported by the study of Ofoegbu and Azarmsa (2010). They stated that IEP assesses student achievement and development to facilitate discussion of the parties involved in determining the strengths, weaknesses, further development, and career path for SLD. However, not all parents were able to attend IEP meetings. Sitti Hasnah (2015) found that parents do not have in-depth knowledge of the IEP implementation process in school. Hence, they refused to get involved due to a lack of knowledge related to IEP. 
Parental support to SLD is to encourage their children to learn skills in vocational subjects taught at SEIP. Learning at home pertains to provide ideas and information to parents about how they can best assist their children with homework and curricular-related decisions and activities. These activities produce a school-oriented family and encourage parents to interact with the school curriculum. Activities to encourage learning at home provide parents with information on what children are doing in the classroom and help them with homework (Durisic \& Bunijevac, 2017). A study by Jamiah (2010) also supports the results of a study that states that parental support is significant to assess students' skills, readiness, and interest with special needs and instill a positive attitude in their children, such as wanting to learn hard work.

In addition, parents also support the school in the form of ideas and help the school in teaching and learning. Parents also participated in the visit and were involved in exhibition activities organized by the school. The study results were consistent with studies by Wendy (2008), who found that parents were also involved in helping children in education. Similarly, a study by Morningstars et al. (2012) stated that family involvement's success gives significant meaning to the collaboration between parents, students, schools, and agencies involved.

However, the results show some constraints in the implementation of SLD career transition in SEIP. Parents are not interested in the activities carried out in school, busy with their affairs and parent's hand over full responsibility of educating their children to teachers in school. The presence of parents to school in this study is only as fulfilling the requirements or invitation of teachers. Parents listen and accept the teacher's suggestions without much question. The findings of this study are in line with the study of Wandry et al. (2008) found that the lack of parental involvement was a huge obstacle to implementing career transition for SLD in SEIP.

The results showed that the presence of parents only as far as attending meetings and listening to briefings from teachers on the implementation of the SLD in SEIP. Parents will follow whatever programs have been planned for their children by the school. The study's findings align with Ibrahim et al. (2021) that SLD cannot understand themselves and parents lack of information because they not involved as decision-makers in determining the direction of education for their children. This is because most schools practiced one-way communication and teachers also provide fewer opportunities for parents to talk or give ideas.

Thus, creating a dynamic relationship between the school and parents is effective communication as the primary strategy to attract parental involvement. Communication is an important activity to attract parents to work with the school, and effective communication between school and home will have positive implications for student development. Moreover, a study by Leontye et al. (2011) confirmed that two-way communication skills between school and home are an attractive force for engaging parents in school.

\section{Conclusion}

The study results found parental involvement in the SLD career transition in SEIP, but parental involvement is not comprehensive. Parents in rural schools were more involved in the SLD career transition than parents in urban schools. Support from parents in 
implementing the career transition is critical to ensure that SLD is more motivated and ready to learn the vocational skills taught at SEIP. The involvement of parents in SLD schooling is also necessary because they are a group that has many advantages compared to special education teachers in carrying out their functions or responsibilities towards their children's schooling. The study results also found that several constraints cause the lack of parental involvement in the career transition of SLD in SEIP. Lack of involvement of SLD mothers in SEIP because they are not interested in the activities carried out by the school, always busy with their work. Parents also hand over full responsibility to the teachers at SEIP to teach and educate their children in school. In this case, to successfully implement the SLD for career transition in SEIP, parents need to be actively involved in the activities carried out by the school. For SLD who study at SEIP, the involvement of parents is significant to ensure that all programs planned in the career transition through vocational education can be implemented effectively. All the skills taught in school need to be practiced at home. So that there is continuity of what is taught in school can be done by SLD at home. Indirectly, the skills taught can be mastered by SLD and they are better prepared to step into the realm of career after they finish school.

\section{Contributions of Theoretical Practice and Contextual Research}

The efficacy of research can impact a specific theory on the study's outcome. Research outcome shows the Taxonomy Model by Kohler (1996) that provides a positive impact towards parents' involvement in determining the success of career transition for students with learning disabilities (SLD) in Special Education Integration Program (SEIP). One of the most effective ways to structure an educational program complying with the students' disabilities based on their differences and disabilities is the parents' involvement. The parents' involvement can be through participation in activities held by the school and discussion with the teachers regarding their child's education throughout the career transition program. This involvement would implant a positive attitude among the children, such as the eagerness to learn, responsibility and hard work. Good values and a positive selfrelying concept are the fundamentals parents need to nurture among children with learning disabilities. Besides that, the school and parents should develop practical communication skills to create an active relationship. This effective communication among the two sides will positively affect the development of students with learning disabilities. Therefore, with constant support from the parents, students with learning disabilities would be more prepared and enthusiastic to gain knowledge and vocational skills as preparation for the career realm.

\section{References}

Al-Mahrezi, A., Al-Futaisi, A., \& Al-Mamari, W. (2016). Learning Disabilities: Opportunities and challenges in Oman. Sultan Qaboos University Medical Journal, 16(2), e129-e131. https://doi.org/10.18295/squmj.2016.16.02.001

Al-Shammari, Z., \& Yawkey, T. D. (2008). Extent of Parental Involvement in Improving the Students' Levels in Special Education Programs in Kuwait. Journal of instructional psychology, 35(2).

Alias, A. (2014). Transition Program: The Challenges Faced by Special Needs Students in Gaining Work Experience. International Education Studies, 7(13), 192-196.

Defur, S. H., Todd-Allen, M., \& Getzel, E. E. (2001). Parent participation in the transition planning process. Career Development for Exceptional Individuals, 24: 19-36. 
Durisic, M., \& Bunijevac, M. (2017). Parental involvement as a important factor for successful education. Center for Educational Policy Studies Journal, 7(3).

Grigal, M., \& Neubert, D. A. (2004). Parents in school values \& post school expectations for transition-aged youth with disabilities. Career Development for exceptional Individuals, 27: 65-85

Ibrahim, R., Abdullah, N., Yassin, M., Handrianto, C., Uçar, A., \& Kenedi, A. (2021). Activities and issues of career transition program for students with learning disabilities (SLD): An initial review. International Journal of Education, Information Technology, and Others, 4(2), 244-251. https://doi.org/10.5281/zenodo.5055147

Ibrahim, R., Razalli, A. R., Handrianto, C., Rahman, M. A., \& Utami, I. W. P. (2021). Selection of vocational education of students with learning disabilities in malaysia: students, parents, and teachers perspectives. IJIET (International Journal of Indonesian Education and Teaching), 5(2), 168-175.

Jamiah, T. (2010). Involvement of Special Education Teachers Towards Students with Learning Disabilities After School In The Central Melaka District. Master Thesis. Faculty of Education. Universiti Kebangsaan Malaysia.

Kochhar-Bryant, C. A., \& Green, G. A. (2009). Pathways to successful transition for youth with disabilities (2nd ed.) Pearson Education.

Kohler, P. D., \& Field, S. (2003). Transition-focused education: Foundation for the future. The Journal of Special Education, 37(3): 174-183.

Landmark, L. J., Ju, S., \& Zhang, D. (2010). Substantiated best practices in transition: fifteen plus years later. Career Development for Exceptional Individuals, 33(3), 165-176. https://doi.org/10.1177/0885728810376410

Leontye, L., Lewis, A., Yanghee, A. K., \& Juanita, A.B. (2011). Teaching practices and strategies to involve inner-city parents at home and in the school. Teaching and Teacher Education 27: 221-234.

Lubbers, J. H., Repetto, J. B., \& McGorray, S. P. (2008). Perceptions of transition barriers, practices, and solutions in Florida. Remedial and Special education, 29(5), 280-292.

Mazzotti, V. L., Test, D. W., \& Mustian, A. L. (2014). Secondary Transition Evidence-Based Practices and Predictors: Implications for Policymakers. Journal of Disability Policy Studies, 25(1), 5-18. https://doi.org/10.1177/1044207312460888

Martin, J. E., Van Dycke, J. L., Christensen, W. R., Greene, B. A., Gardner, J. E., \& Lovett, D. L. (2006). Increasing student participation in IEP meetings: Establishing the self-directed IEP as an evidenced-based practice. Exceptional Children, 72(3), 299-316.

Maslinda D., Mohd S. N., \& Muhammad S. S. (2012). Students with special needs and learning difficulties from school to career. Journal of Social Science, 5 (1): 42 -46 .

Morningstar, M. E., Bassett, D. S., Kochhar-Bryant, C., Cashman, J., \& Wehmeyer, M. L. (2012). Aligning transition services with secondary education reform: A position statement of the Division on Career Development and Transition. Career Development and Transition for Exceptional Individuals, 35(3), 132-142.

Mustapha, R. (2004). IT and multimedia literacy in technical and vocational education in Malaysia. International journal of digital contents, 2(1), 113-115.

Norshidah, M. S., Zuria, M., \& Zalizan, M. J. (2003). Collaboration Between Parents And Schools In Special Education. Short Term Project Report GG/009/2001. Universiti Kebangsaan Malaysia. 
Ofoegbu, N. E., \& Azarmsa, R. (2010). Impact of the Special Education Vocational Education Program (VEP) on Student Career Success. International Journal of Special Education, 25(2), 34-46.

Reichman, A., \& Jacoby, S. (2010). A life time of learning and earning: A family guide to work preparation for deaf and hard of hearing high school students. www.clerccenter.gallaudet.edu.

Samian, S. S., \& Buntat, Y. (2012). Self-employment: Perception among deaf students in Malaysia higher education through workplace experiences.

Tozer, S. E., Senese, G., \& Violas, P. C. (2006). Schooling And Cultural Hegemony. School And Society: Historical And Contemporary Perspectives. New York: The McGraw-Hill.

Wandry, D. L., Webb, K. W., Williams, J. M., Bassett, D. S., Asselin, B. B., \& Hutchinson, S. R. (2008). Teacher candidates' perceptions of barriers to effective transition planning, Career Development for Exceptional Individuals, 31: (14-25).

Yusof, A. M., Ali, M. M., \& Salleh, A. M. (2014). Employability of vocational school leavers with disabilities. Procedia-Social and Behavioral Sciences, 112, 1064-1069.

Zalizan, M. J. (2009). Education Of Children With Special Needs. Concepts And Practices. Bangi: Universiti Kebangsaan Malaysia Publishers. 